only out of a full understanding of the normal, especially when there is additional stress, however natural, on the body.

Another ro years have elapsed. Where are we now? I have great pleasure in asking Dr Leitch to tell us.

\title{
REFERENCES
}

Garry, R. C. \& Stiven, D. (I935-6). Nutr. Abstr. Rev. 5, 855.

Garry, R. C. \& Wood, H. O. (1945-6). Nutr. Abstr. Rev. 15, 59 I.

\section{Changing concepts in the nutritional physiology of human pregnancy}

\section{By Isabella Leitch, Commonwealth Bureau of Animal Nutrition, Bucksburn, Aberdeenshire}

It seems to me sometimes that famous dicta of famous men, if repeated often enough, have the unfortunate effect of sterilizing thought instead of enlivening it. For instance the dictum of Claude Bernard that 'La fixité du milieu interieur c'est la condition de la vie libre', by focusing the attention of physiologists and biochemists on the static aspect of the composition of bodies, and on physiological devices and dietary requirements to maintain the static equilibrium, may have contributed to a somewhat rigid attitude of mind. So many are still reluctant to recognize that the equilibrium of the milieu intérieur may be set at different levels in the same organism and they continue to regard as pathological much of the amazing range of variation that is, in fact, compatible with healthy life. Pregnancy offers an outstanding example of this.

\section{Twenty years ago}

When Garry \& Stiven (1935-6) wrote the first review of metabolism in pregnancy for Nutrition Abstracts and Reviews, 20 years ago, it was customary to assess the normality of the pregnant woman, for instance in respect of composition of the blood and basal metabolic rate, by comparison with accepted standards for non-pregnant women, and inquiries about diet were concerned with how much extra protein or calcium or iron the pregnant woman might require to supply the foetus and additional maternal tissues. And this attitude persisted although it had already been demonstrated that, on any ordinary diet in this country or America, the pregnant woman stored nitrogen and structural minerals in amounts far in excess of those in foetus and maternal accessory tissues. 'The diagnosis of anaemia' the review says 'will depend on the "normal" standard adopted for non-pregnant women, which is difficult to define, since the range of variation is wide'. And, of course, a diagnosis of anaemia meant the prescription of iron.

On the other hand, we have this pearl of wisdom following a review of studies of birth weight: 'Hence, it is possible that, under any but extreme conditions, the birth weight of the child depends less on the food intake of the mother than on its 
own growth impulse and the mother's constitution'. We shall find that the most recent research does not greatly alter that statement.

\section{Ten years ago}

When Garry prepared his second review, with Wood, for Nutrition Abstracts and Reviews (Garry \& Wood, I945-6), the point of view had shifted and was much more epidemiological than Io years earlier. It was recognized that there is an optimum age for reproduction; that the commonest cause of neonatal death was prematurity which must be regarded as a failure of the reproductive process. The emphasis was on ignorance. 'Our present knowledge of the physiology and biochemistry of mother and foetus is woefully scanty'. In relation to haemoglobin levels and anaemia: 'There is a woeful lack of detailed information .... The position is serious since on the significance to be attached to these latter readings [for blood, plasma and red-cell volumes] will depend the rational practice of obstetricians and even the nutritional policy to be adopted by the state'.

It might be thought that, once the facts of water retention to increase blood volume and of a substantial rise, estimated then as $16 \%$, of red cells, had been established, the question of anaemia might have been soluble on the basis suggested by Garry \& Wood of whether the increase in total oxygen-carrying capacity of the blood was adequate for the increased demands, taking into account the shift in the dissociation curve of oxyhaemoglobin to the right, as had been demonstrated by Barcroft, Elliott, Flexner, Hall, Herkel, McCarthy, McClurkin \& Talaat (I934-5). And perhaps it might have been so resolved had not a long line of clinical findings, headed by those of Widdowson (1939) shown that iron given to pregnant or nonpregnant women would raise haemoglobin to conventionally 'normal' levels. Since nutrition experts preached the 'therapeutic test' as the very criterion of deficiency, here was, indeed, proof of deficiency and the dispensers of iron went from strength to strength, in spite of occasional doubting voices.

Much attention was still given to studies of the diets of pregnant women, often by the most doubtful methods, and supplements to diets considered unsatisfactory were credited with extraordinary clinical effects. It will be my purpose to try to show how far we have now progressed in the re-interpretation of data and the re-orientation of attitudes of mind which Garry, in his characteristically cautious way, almost predicted.

\section{Inconstancy of the milieu}

\section{Today}

To establish the idea that an organism, here in particular a woman when she becomes pregnant, can set up an entirely new equilibrium in the internal milieu and that over, say, a thousand women there is an almost incredible range in the extent of the changes that occur, let me summarize briefly what happens. She, the pregnant woman, may put on no weight at all, or $45 \mathrm{lb}$. or more and, doing so, may produce a baby at term that weighs anything from 5 to $10 \mathrm{lb}$. without much relation to her own weight gain. She will increase the volume of her plasma by anything between 
14 and $121 \%$ and her total extracellular water by nearly three times as much. She will manufacture new red cells sufficient to raise total circulating haemoglobin by about $15 \%$ with much less variation than in plasma volume, and, in order that oxygen may be unloaded at higher tensions and carbon dioxide more readily picked up, she will overbreathe, raise the hydrogen-ion concentration of her blood and shift the oxygen-dissociation curve of her blood to the right. All of that adds up to a highly pathological condition by non-pregnant standards, but while so handicapped (by non-pregnant standards) the pregnant woman will improve her digestion and absorption and go about her ordinary business. And, having built up this entirely new 'way of life' to a climax at 36 weeks, she will undo most of it during the next 6 weeks.

Clearly, we require criteria of normality for pregnancy that will be relevant to the events of pregnancy. Some may be taking shape through the mists of unexplained variation, but there are many problems to solve before the whole picture will be clear. Let us look at some of the separate points.

\section{Maternal weight gain}

Since the recorded weight gains in pregnancy vary so widely, and we do not at present know why, and so cannot usefully rationalize in terms of averages, we have estimated what happens in a hypothetical reference pregnant woman who represents the average primipara in Aberdeen. The resulting picture is compounded of acceptable measurements, adapted to this woman. It is outlined in Table $\mathrm{x}$. Included in the $4.1 \mathrm{~kg}$ which persists after parturition is $0.27 \mathrm{~kg}$ of red blood cells which represent a surplus of $60 \mathrm{~g}$ haemoglobin, roughly one-tenth of the prepregnant total. Also included is nearly I $\mathrm{kg}$ of breast tissue. The following deductions appear logical.

\section{Table I. Weight increase ( $\mathrm{kg}$ ) during pregnancy}

(Hypothetical reference Aberdeen primipara: age 24; height $162 \mathrm{~cm}$; prepregnant weight $54 \mathrm{~kg}$ )

\begin{tabular}{|c|c|c|}
\hline Total weight gain & $12 \cdot 5$ & \\
\hline Product of conception & 5.0 & \\
\hline Foetus & & 3.23 \\
\hline Placenta & & 0.64 \\
\hline Liquor amnii & & $1 \cdot 44$ \\
\hline Maternal net gain & $7 \cdot 5$ & \\
\hline Components of maternal gain: & & \\
\hline Water & $6 \cdot 0$ & \\
\hline Plasma & & $\mathrm{I} \cdot 2^{*}$ \\
\hline Extravascular, extracellular & & $2 \cdot 2^{*}$ \\
\hline Intracellular & & $2 \cdot 6$ \\
\hline Protein & I. 5 & \\
\hline
\end{tabular}

\section{Blood dilution}

We may calculate by simple proportion that, if plasma is diluted to nearly $140 \%$ of its original volume and red cells increase by only I $5 \%$, then blood is diluted to $\mathrm{I}_{3} \mathrm{O} \%$ of its original volume and the concentration of haemoglobin will be $\mathrm{II}_{5} / \mathrm{I}_{3} \mathrm{O}$, or roughly $88 \%$ of prepregnant concentration, provided haemoglobin per cell does 
not change. The significance of this calculation for the diagnosis of anaemia in pregnancy appears obvious, but clinicians in general seem extremely reluctant to admit that the argument is valid. There are two main facts that seem to me to exclude the concept of anaemia under these circumstances. The first is that the nonpregnant human being with an average amount of $14 \mathrm{~g}$ haemoglobin/ $100 \mathrm{ml}$. blood, if short of oxygen, can raise the level to $20 \mathrm{~g}$, that achieved by the Everest mountaineers. Presumably if the pregnant woman were short of oxygen with I I g haemoglobin, she would raise it by the same amount, which, in her expanded plasma volume would give a concentration of about $14.5 \mathrm{~g} / \mathrm{roo} \mathrm{ml}$. That she can do so is shown by the fact that, under the stimulus of medicinal iron, she will do it as nonpregnant women and men will, under the same stimulus (see Garry, Sloan, Weir \& Wishart, 1954). But, unless prodded, she does not do it.

The second point is that the ultimate criterion of iron-deficiency anaemia is mean cell haemoglobin concentration and that is not related to the degree of dilution of the red-cell suspension in pregnancy, but remains normal in most. And when all is said and done, pregnant women with a haemoglobin concentration of II $\mathrm{g} / \mathrm{I00} \mathrm{ml}$. blood and a total increase of $15 \%$ in haemogiobin are perfectly well and know no improvement when forced to increase their red cells. A fuller exposition of this argument with suggestions of how the forced extra red cells and haemoglobin may be a handicap, not a help, appears in a review by Hytten \& Duncan (1956).

\section{Total extra water}

There is no clear evidence about the stimulus to, or control of, the accumulation of water in pregnancy. Seitchik \& Alper (1956) explain a gain of intracellular water as deposited with the protein retained in excess of foetal needs, to increase lean body mass; and they demonstrate that, in the five women they studied, gain of extracellular water and lean body mass was offset by loss of fat. This is akin to a rough weight balance like that in Table $I$ and, in my opinion, the loss of fat probably means no more than that the women ate too little, either voluntarily in accordance with the American craze for 'calorie-free' diets, or under medical guidance to prevent pre-eclampsia. Seitchik \& Alper do not discuss the build up of extracellular water in plasma and extravascular space, but we can throw some light on its distribution and suggest possible reasons. We know from recent research (Kayser, 1953-4; Burwell, 1954) that the vascular bed of the uterus takes $500 \mathrm{ml}$. blood/min. Since the prepregnant output of the heart is about $4 \mathrm{l} . / \mathrm{min}$ and the output in late pregnancy 5.75 or $61 . / \mathrm{min}$, the amount circulating in the uterus is no more than a third or a quarter of the extra blood in use. Of the remaining extra blood a little goes to the lungs, but the major part circulates in the periphery, which suggests that the dissipation of heat is of vital importance. And it is not unreasonable to suppose that accumulation of heat in mother and foetus would be disastrous.

About hormonal control of accumulation of water, one may remember that, at the 1943 Symposium, Newton (1944) described how, if the foetuses are removed from mice but the placentas left, weight is not lost and the placentas are delivered at term. Logically a potent substance causing retention of water or sodium or both 
might be expected to occur in the placenta, but, so far, has not been found (see Barnes \& Quilligan (1956) who looked for one). The answer may not be simple, for Dieckmann \& Pottinger (1956) claim that the normal pregnant woman retains both water and sodium, but the pre-eclamptic and eclamptic retains water only; sodium in muscle and skin is at non-pregnant level and abnormal for pregnancy.

The question of dissipating heat brings us naturally to the question of the origin of the extra heat eliminated.

\section{Heat production}

Twenty years ago, during an era when much work on basal metabolic rate was done, there were two opposed views as described by Garry \& Stiven (1935-6); one, that an increase of $20 \%$ or more over that of similar non-pregnant women, which is still accepted as usual, could be explained on the basis of the oxygen consumption of the foetus and added maternal tissues; the other that the increase was greater than could be so explained and implied an increase of thyroid activity. Now we believe that the second view was right, but not the consequent deduction. We offer the following estimates. Our reference woman, at the beginning of pregnancy, may have a basal energy expenditure of $135^{\circ}$ Cal. The increase in weight alone, assuming the increase to have the same average composition as the body, would raise basal metabolism to $\mathrm{r} 470 \mathrm{Cal}$. an increase of only $9 \%$. The result is different if we take expenditure bit by bit. Romney, Reid, Metcalfe \& Burwell (I955) of Harvard University estimated the oxygen consumption of the pregnant uterus and its contents, excluding liquor amnii, to be at least $5 \mathrm{ml} / \mathrm{kg} / \mathrm{min}$. If this be correct, the total heat equivalent for a day would be about 175 Cal. The other components of the rise in basal heat production are the metabolism of added tissues, including that in the breasts, which we reckon to be about $36 \mathrm{Cal}$; the extra work of the heart which is of the order of $80 \mathrm{Cal}$. and about $20 \mathrm{Cal}$. for the extra work of respiration, making a total of $310 \mathrm{Cal}$. or $23 \%$ of the prepregnant rate. The extra work of the heart is calculated as follows. If mean aortic pressure be $105 \mathrm{~mm}$ and the output of the heart in the non-pregnant woman be $41 . / \mathrm{min}$, the work of the heart is 14 cal./min or, on the assumption of an energetic efficiency of $10 \%, 200 \mathrm{Cal} . /$ day. If the output at about its maximum in pregnancy be $5.751 . / \mathrm{min}$ the work is 18.5 $\mathrm{cal} . / \mathrm{min}$, or $266 \mathrm{Cal}$./day, giving an increase of $66 \mathrm{Cal}$. The additional work of the right heart may be about one-quarter of that, giving a total increase of about 80 Cal.

It will be noted that of the total of 310 extra Cal., at least 175 are produced by the foetus, not more than $\mathrm{r} 35$ by the mother. The extra heat the mother herself produces is explained in terms of the work of heart and respiration and new metabolizing tissue, but the greater part of the extra heat eliminated is passively received from the foetus to be transmitted and dissipated. It is evident that no increase in activity of the thyroid need be postulated to account for the rise in heat output; indeed the foetal heat generated might be expected to depress the activity of the maternal thyroid. 
The supply system : the placenta

Those who were at the 1943 Symposium may remember Barcroft's (r944) rejection of Needham's view that the placenta is merely an ultrafilter, a rejection most amply confirmed by more recent work with isotopes and electrophoresis which suggests that the placenta is not in any sense a passive membrane, but that nutrients are broken down and rebuilt to form for instance the characteristic plasma proteins and haemoglobin of the foetus, in which the amino-acid make-up differs greatly from that of maternal haemoglobin or plasma proteins.

\section{Oxygen supply}

It is not only minerals and large organic molecules that have to be considered. Barcroft (1944) described how, at the end of pregnancy in the sheep, there is little or no oxygen gradient between maternal and foetal blood; by the time birth is due all the devices to facilitate oxygen transfer have been 'very completely exploited'. Walker \& Turnbull (I953) have since shown that the oxygenation of human foetal blood may flag during the last month, as shown by rise of foetal haemoglobin in response to the anoxia, and that if birth does not take place at the usual time, the supply to the postmature foetus may be so low that foetal haemoglobin rises to the maximum of $20 \mathrm{~g}$ haemoglobin/100 $\mathrm{ml}$., the level attained by the Everest mountaineers, and even that may not be sufficient to prevent anoxic injury and even death.

There is not enough information to show whether the size of the placenta, or its continued growth into late pregnancy, may affect the adequacy of the supply of oxygen, and presumably other nutrients, in late pregnancy, or whether failure of supply means primary degenerative changes in the placenta. But at least we do know that even the postmature foetus sometimes gets enough.

\section{Gradients}

We are all familiar with the concept of gradients from mother to foetus in the sense that the mother's blood is expected to carry more of everything the foetus needs so that there is a pressure head to ensure a continuous flow. Dr Hytten and I, for another purpose, summarized recent work on the composition of maternal and foetal blood with the result shown in Table 2. In view of what we know about the differ-

Table 2. Comparison of maternal and foetal bloods at term

\begin{tabular}{|c|c|c|}
\hline Component & $\begin{array}{c}\text { Foetal blood level } \\
\text { lower }\end{array}$ & $\begin{array}{c}\text { Foetal blood level } \\
\text { higher }\end{array}$ \\
\hline Sugar & Glucose & Fructose \\
\hline Protein & $\begin{array}{c}\text { Total protein } \\
\alpha \text { - and } \beta \text {-globulins }\end{array}$ & $\begin{array}{l}\text { Albumin } \\
\gamma \text {-globulin }\end{array}$ \\
\hline Amino-acids & - & All \\
\hline Fats and lipids & Fatty acids & - \\
\hline Inorganic elements & $\mathrm{Ca}, \mathrm{P}$ and $\mathrm{Fe}$ & - \\
\hline Vitamins & $\begin{array}{c}\text { Vitamin C } \\
\text { Fat-soluble vitamins }\end{array}$ & $\begin{array}{l}\text { Riboflavin } \\
\text { Vitamin } B_{12}\end{array}$ \\
\hline
\end{tabular}


ences in amino-acid make-up between maternal and foetal proteins, it is clear that the position is much more complicated than was once thought, especially since inorganic iron, which does appear to have a pressure head, nevertheless is almost certainly 'ferried' across by the protein ferritin.

\section{Birth-zueight again}

I will repeat the passage I quoted earlier from Garry \& Stiven: ‘ . . . the birth weight of the child depends less on the food intake of the mother than on its own growth impulse and the mother's constitution'. In support of that deduction we now have the very remarkable study by Morton (1955) of the inheritance of human birth weight based on data collected in Hiroshima and Nagasaki between 1948 and 1952. In non-statistical language, maternal half-sibs, children of the same mother but different fathers, were much more closely alike in birth weight than paternal half-sibs, children of the same father but different mothers. In pairs of twins, the resemblance in birth weight of twins of different sex was just as close as that of twins of the same sex, though many of the like-sexed twins would be 'identical'. Further, when full sibs, with both parents the same, were compared each with an adjacent sib and with one removed by one or two places, the resemblance in birth weight decreased in the order $0.52: 0.42: 0.36$. All of this shows that the environment the mother provides is much more potent than the genetic make-up of the child in determining birth weight, and also that the maternal environment is not constant over the reproductive period, but changes, probably with both age and parity. Dr Thomson (1957) will have further evidence in the same direction to give.

\section{Conclusion}

There are two main lessons from this brief review.

(x) We must learn to think of criteria of normality as specific, and even phasespecific, so that we may some day say with confidence: this is normal in a 24 -year-old woman in the $5^{\text {th }}$ month of her second pregnancy, and that is normal for a 35 -yearold primipara at term. And by 'normal' we shall mean not average values but that the women in question have successfully made the necessary changes in their milieu interieur, that they are well, and that the prospects for the foetus are bright. At the present moment we have little idea whether the range will be wide or narrow.

(2) Certainly pregnancy is not a pathological process as Garry \& Wood (1945-6) said, and the pregnant woman should not require routine medicinal treatment; but the large adjustments of her own body, that are called for in the most abrupt manner, are not always easily made. A first pregnancy is more often a failure than the next two or three; after a certain age failures are more likely to occur whatever the number of children already born. Vital statistics show that there is an excess of premature births among the stunted and chronically less-than-healthy women who are themselves the products of unemployment, poverty and poor diet. The performance is equally unsatisfactory among the better grown and apparently healthy women who, for economic reasons, postpone childbearing too long. We can see that the process of becoming 'well grown' fades gradually, not to a static adult state, but to 
a condition of waiting equilibrium ready to go on to the changes of pregnancy. There is a certain continuity; 'the end is in the beginning'. Perhaps that concept might inspire physiologist and epidemiologist to work more together to discover whether either medicine or social medicine can do anything more to explain or prevent reproductive failures.

\title{
REFERENCES
}

Barcroft, J. (1944). Proc. Nutr. Soc. 2, I4.

Barcroft, J., Elliott, R. H. E., Flexner, L. B., Hall, F. G., Herkel, W., McCarthy, E. F., McClurkin, T. \& Talaat, M. (1934-5). F. Physiol. 83, 192.

Barnes, A. C. \& Quilligan, E. J. (1956). Amer. F. Obstet. Gynec. 71, 670.

Burwell, C. A. (1954). Fohns Hopk. Hosp. Bull. 95, I 15.

Dieckmann, W. J. \& Pottinger, R. E. (1956). Amer. F. Obstet. Gynec. 71, 596.

Garry, R. C., Sloan, A. W., Weir, J. B. de V. \& Wishart, M. (1954). Brit. Ұ. Nutr. 8, 253.

Garry, R. C. \& Stiven, D. (I935-6). Nutr. Abstr. Rev. 5, 855.

Garry, R. C. \& Wood, H. O. (1945-6). Nutr. Abstr. Rev. 15, 59 I.

Hytten, F. E. \& Duncan, D. L. (1956). Nutr. Abstr. Rev. 26, 855.

Kayser, H. W. (1953-4). Arch. Gynäkol. 184, 385.

Morton, N. E. (1955). Ann. hum. Genet. 20, I25.

Newton, W. H. (1944). Proc. Nutr. Soc. 2, I3.

Romney, S. L., Reid, D. E., Metcalfe, J. \& Burwell, C. S. (1955). Amer. Y. Obstet. Gynec. 70, 79 I.

Seitchik, J. \& Alper, C. (1956). Amer.F. Obstet. Gynec. 71, I165.

Thomson, A. M. (1957). Proc. Nutr. Soc. 16, 45.

Walker, J. \& Turnbull, E. P. N. (1953). Lancet, 265, 3 1 2.

Widdowson, E. M. (1939). Lancet, 237, 640 .

\section{Technique and perspective in clinical and dietary studies of human pregnancy}

\author{
By A. M. Thomson, Obstetric Medicine Research Unit (Medical Research Council), \\ Department of Midwifery, University of Aberdeen
}

Before and during the 1939-45 war, a number of field surveys and feeding experiments seemed to show dramatically, though imprecisely, that a good diet helps to ensure normal pregnancy and childbirth; and our wartime food policy, which gave preferential treatment to pregnant women, was accompanied by a sharp fall in the stillbirth and neonatal death rates. But exact scientific information was, and still is, meagre. In 1946, Garry \& Wood (1945-6) noted the development of 'a more critical attitude, even of disillusionment', contrasting with the earlier optimism. The results of recent clinical and dietary investigation have been persistently barren (Sontag \& Wines, 1947; Hobson, 1948; Macy, Moyer, Kelly, Mack, Di Loreto \& Pratt, 1954; McGanity, Bridgforth, Martin, Newbill \& Darby, I955).

We are thus faced with a dilemma: on the one hand, a not unreasonable belief backed by much cogent evidence that the nutrition of pregnant women must be important, and on the other hand, the failure of survey methods to prove that this is so. I shall try to show that the difficulty is one of technique and of perspective. The analysis that follows is based upon the experience of a research team which 